\title{
Stability of Slow-Rusting Resistance to Puccinia asparagi and Managing Rust in Asparagus
}

\author{
Dennis A. Johnson, Department of Plant Pathology, Washington State University, Pullman, WA 99164-6430
}

\begin{abstract}
Johnson, D. A. 2012. Stability of slow-rusting resistance to Puccinia asparagi and managing rust in asparagus. Plant Dis. 96:997-1000.

The stability of slow-rusting resistance to Puccinia asparagi in several asparagus cultivars was evaluated in two replicated field trials. Rust epidemics were monitored in each trial for 8 years spanning a period of 13 years (1983-1990 and 1987-1995). Inoculum of P. asparagi, an autoecious macrocyclic rust, originated each year as teliospores. In the first trial, the cultivars Jersey Titan, Jersey Centennial, Jersey Giant, Delmonte-361, and UC-157 had consistently lower area under the disease progress curve (AUDPC) values than Wash T2 and WSU-1. Cultivar Mary Washington was intermediate between the two groups of resistant and susceptible cultivars in 6 of 8 years. Jersey Titan consistently ranked number 1 for resistance with the lowest AUDPC values all 8 years. In the second trial, Jersey Giant, Delmonte-361, and UC-157

had consistently lower AUDPC values than Larac, Gynlim, Cito, Largo 17-3, and Franklim in each of 8 years. Jersey Giant, Delmonte-361, and UC-157 always ranked low $(1,2$, or 3$)$ for AUDPC. A shift from rust-susceptible to rust-resistant asparagus cultivars began in central Washington around 1996. In 2011, resistant cultivars made up nearly 96\% of the asparagus plantings. From 1996 to 2011, rust was not considered a problem in commercial fields with slow-rusting resistant cultivars. Use of durable, slow-rusting cultivars, along with sanitation practices that reduced levels of aecia in nonharvested nurseries and on volunteer asparagus plants and judicious irrigation management, has effectively managed asparagus rust in commercial fields for at least 29 years in south-central Washington.
\end{abstract}

Puccinia asparagi DC. in Lam. \& DC., the causal agent of asparagus rust, is an autoecious macrocyclic rust that produces pycnia, aecia, uredinia, and telia in succession. Rust outbreaks occur sporadically on asparagus in south-central Washington, where over 13,000 ha of asparagus were grown in the 1980s. The area cropped to asparagus declined to 10,300 ha in $1993,9,000$ ha in 1997, and 2,850 ha in 2011. Asparagus is irrigated in this semiarid environment. Rust epidemics are associated with rain or frequent dews (24) and the application of excessive amounts of water by sprinklers. When rust is severe, asparagus foliage ripens prematurely and carbohydrate storage in the crown is reduced, resulting in reduced yield the following spring (24). Yields of susceptible asparagus cultivars were substantially reduced by rust epidemics, whereas yields of resistant cultivars were not. A cumulative effect of rust infection on yield of the susceptible cultivars was seen in that yield reductions were greater after a second rather than the first year of infection (20).

Resistance is recognized as an efficient means of managing rust in asparagus $(6,12)$. Since the early 1900 s, much effort has been directed toward identifying and developing resistant asparagus cultivars $(2,12,29,34)$. Disease resistance is an active process in which the host opposes, completely or in some degree, the effect of a pathogen (19). Rust resistance used in asparagus cultivars has been quantitative rather than qualitative, resulting in differences in intensity of infection $(12,16,34)$. Rust development, as measured by area under the disease progress curve (AUDPC) in the field, is less on resistant cultivars than on susceptible cultivars. A relatively long latent period and low infection frequency are associated with rust resistance in asparagus $(16,18)$. This type of resistance has been termed "slow-rusting" $(16,26,33)$, dilatory resistance $(4)$, and partial resistance $(13,35)$.

Resistance in asparagus infected with $P$. asparagi in the field behaved as a quantitatively inherited trait, in that progeny from vari-

Corresponding author: Dennis A. Johnson, E-mail: dajohn@wsu.edu

Accepted for publication 2 February 2012.

http://dx.doi.org/10.1094/PDIS-09-11-0797-RE

(C) 2012 The American Phytopathological Society ous crosses were continuously distributed from low to high values of AUDPC (21). Resistance in juvenile asparagus plants, as measured by the quantity of uredinia on stems, behaved similarly in the greenhouse and was estimated to be conditioned by at least four or five genes (12). Considerable variation for resistance exists within asparagus populations (17).

Asparagus rust can be effectively managed in central Washington with a combination of rust resistance, sanitation practices that reduce incidence of aecia in the spring, irrigation water management, and in some years, timely applications of fungicides $(10,20)$. Slow-rusting cultivars grown in the Columbia Basin include Jersey Giant, Jersey Centennial, and Delmonte-361 (16). Rust resistance that is effective and durable is the main component of an integrated rust management strategy for asparagus. Resistance has been shown to effectively reduce rust in asparagus cultivars (20), but the durability of the resistance in asparagus to rust has not been documented. The purpose of this work was to evaluate durability of rust resistance in asparagus cultivars over many years.

\section{Materials and Methods}

Two sets of plots were established from seedlings transplanted to a fine sandy loam soil at the Irrigated Agriculture Research and Extension Center near Prosser, WA. In both sets of plots, transplants were spaced 26 to $30 \mathrm{~cm}$ apart in furrows 15 to $17 \mathrm{~cm}$ deep, and rows were spaced $1 \mathrm{~m}$ apart. Entries were arranged in a randomized complete block design for the first set of plots and in a completely random design in the second set. The first set of plots was established April 1983 and was maintained through October 1990; the second set was established April 1987 and was maintained through October 1995. The two sets of plots were separated by approximately $0.8 \mathrm{~km}$.

The first set of plots consisted of eight asparagus cultivars in three-row plots, three $\mathrm{m}$ long, replicated six times (Table 1). Entries Jersey Titan, Jersey Centennial, Jersey Giant, Demonte-361, and UC-157 were chosen because of reported rust resistance $(1,8)$. Mary Washington, Wash T2, and WSU-1 were chosen because they were grown in Washington and to serve as susceptible standards.

The second set of plots consisted of 11 cultivars in single-row plots, $10.7 \mathrm{~m}$ long, replicated five times. Rust-resistant cultivars Jersey Giant, Delmonte-361, and UC-157, and nine cultivars from Europe, were chosen to evaluate resistance to P. asparagi (Table 2). 
Sprinkler irrigation was used to irrigate plants and to encourage rust development. A border row of each plot of the first set of plots was inoculated in May 1983 with approximately $5 \times 10^{5}$ urediniospores of P. asparagi per $\mathrm{ml}$ of oil (Soltrol 170, Phillips Chemical Co., Bartlesville, OK). The urediniospore suspension was sprayed with a 3-liter hand pump garden sprayer until a thin film of oil was just visible on plants. Urediniospores were collected in bulk from asparagus plants in a field near Prosser, WA, in 1982 and increased on WSU-1 in the greenhouse.

Uredinia developed on asparagus foliage following artificial inoculation during the 1983 season in the first set of plots, and from naturally occurring inoculum in the second set of plots during the 1988 season. Telia developed on foliage toward the end of the growing season, and following initial rust development in both sets of plots, foliage with telia was left in the field to overwinter at the end of each season. Subsequent epidemics in both sets of plots originated from naturally occurring inoculum. Rust epidemics were monitored from 1983 to 1990 in the first set of plots and from 1988 to 1995 in the second set of plots.

Rust severity was estimated as the proportion of surface area of the host covered with uredinia in each plot, using the modified Cobb's scale for cereal rust (30). Rust severity was estimated at 14day intervals, usually beginning in mid-June and until mid-September of each year. The AUDPC was calculated for each plot to indicate the slow-rusting character of the cultivars. Data for AUDPC and ranking of cultivars for AUPDC were each subjected to analysis of variance using the PROC GLM procedure of SAS (SAS Institute Inc., Cary, NC). Fisher's protected LSD at $P=0.05$ was used to compare treatment means.

Funding did not continue to maintain plots beyond 1995. Consequently, to determine how slow-rusting cultivars were performing, commercial fields were observed for rust by the author and growers. In addition, the manager of the Washington Asparagus Commission and field consultants who regularly visited the fields were interviewed from 1996 to 2011. Information obtained in interviews included cultivars grown and severity of any rust present. At least $75 \%$ of the land cropped to asparagus was represented each year.

\section{Results}

Rust developed on all cultivars each year except the most resistant cultivars (Jersey Titan, Jersey Centennial, and Jersey Giant) in the first year (1983) in the first set of plots (Table 1). Severity of rust was high in plots of susceptible cultivars each year except 1983 and 1986 in the first set of plots, and 1990 in the second set of plots. Rust severity was considered low in 1983 and moderate in 1986 and 1990. Cultivars considered resistant were Jersey Titan, Jersey Centennial, Jersey Giant, Delmonte-361, and UC-157 in the first set of plots (Table 1) and Jersey Giant, Delmonte-361, and UC-157 in the second set of plots (Table 2).

AUDPC varied significantly $(P<0.05)$ among asparagus cultivars each year in both sets of plots (Tables 1 and 2$)$. Significant $(P<$ $0.001)$ year $\times$ cultivar interactions were evident for both sets of plots. However, specific cultivars consistently had low AUDPC values relative to other cultivars (Tables 1 and 2). For example, in the first set of plots, Jersey Titan, Jersey Centennial, Jersey Giant, Delmonte361, and UC-157 had consistently lower AUDPC values than Wash T2 and WSU-1. Mary Washington was intermediate between resistant and susceptible in 6 of 8 years (Table 1). Jersey Titan consistently ranked number 1 with the lowest AUDPC values every year, and Wash T2 and WSU-1 ranked either seventh or eighth (highest ranking for susceptibility) each of the 8 years (Table 3 ).

In the second set of plots, Jersey Giant, Delmonte-361, and UC157 had consistently lower AUDPC values than Larac, Gynlim, Cito, Largo 17-3, and Franklim in all 8 years (Table 2). The AUDPC value for Lucullus 310 did not vary significantly from those of the most resistant cultivars in 4 of the 8 years. Franklim had significantly higher AUDPC values than all other cultivars each year. Jersey Giant, Delmonte-361, and UC-157 were always ranked 1, 2, or 3 for AUDPC (Table 4). Lucullus 310, Lucullus 234, and Tainan 1 consistently ranked between 4 and 9, and Franklim always ranked number 11 (most susceptible) (Table 4).

Table 1. Area under the disease progress curve of asparagus cultivars infected with Puccinia asparagi in plots near Prosser, WA, from 1983 to $1990^{z}$

\begin{tabular}{|c|c|c|c|c|c|c|c|c|}
\hline \multirow[b]{2}{*}{ Cultivar } & \multicolumn{8}{|c|}{ Year } \\
\hline & 1983 & 1984 & 1985 & 1986 & 1987 & 1988 & 1989 & 1990 \\
\hline Jersey Titan & $0 \mathrm{a}$ & $29 \mathrm{a}$ & $50 \mathrm{a}$ & $4 \mathrm{a}$ & $3 \mathrm{a}$ & 89 a & $17 \mathrm{a}$ & $62 \mathrm{a}$ \\
\hline Jersey Centennial & $0 \mathrm{a}$ & $84 \mathrm{a}$ & $112 \mathrm{a}$ & $16 \mathrm{a}$ & $136 \mathrm{a}$ & $276 a b$ & $58 \mathrm{a}$ & $149 \mathrm{ab}$ \\
\hline Jersey Giant & $0 \mathrm{a}$ & $319 a b$ & $90 \mathrm{a}$ & $16 \mathrm{a}$ & $119 \mathrm{a}$ & $254 \mathrm{ab}$ & $98 \mathrm{a}$ & $221 \mathrm{ab}$ \\
\hline Delmonte-361 & $0.1 \mathrm{a}$ & $184 \mathrm{a}$ & $127 \mathrm{a}$ & $28 \mathrm{a}$ & $159 \mathrm{a}$ & $446 a b$ & $81 \mathrm{a}$ & $276 \mathrm{~b}$ \\
\hline UC-157 & $1 \mathrm{a}$ & $429 \mathrm{~b}$ & $228 \mathrm{ab}$ & $20 \mathrm{a}$ & $168 \mathrm{a}$ & $545 \mathrm{~b}$ & $93 \mathrm{a}$ & $206 \mathrm{ab}$ \\
\hline Mary Washington & $6 \mathrm{ab}$ & $1,112 \mathrm{c}$ & $330 \mathrm{~b}$ & $122 \mathrm{a}$ & $621 \mathrm{~b}$ & $1,402 \mathrm{c}$ & $328 \mathrm{~b}$ & $749 \mathrm{c}$ \\
\hline Wash T2 & $10 \mathrm{bc}$ & $1,480 \mathrm{~d}$ & $567 \mathrm{c}$ & $276 \mathrm{~b}$ & $1,047 \mathrm{c}$ & $2,350 \mathrm{~d}$ & $629 c$ & $1,110 \mathrm{~d}$ \\
\hline WSU-1 & $16 \mathrm{c}$ & $1,699 \mathrm{~d}$ & $716 \mathrm{c}$ & $372 \mathrm{~b}$ & $1,680 \mathrm{~d}$ & $2,856 \mathrm{e}$ & $832 \mathrm{~d}$ & $1,419 \mathrm{e}$ \\
\hline
\end{tabular}

${ }^{\mathrm{z}}$ Within a column, values followed by the same letter are not significantly different at $P=0.05$ according to Fisher's protected LSD. Values are means of six replicates. Rust severity was estimated using the modified Cobb's scale for cereal rust at 14-day intervals, usually from mid-June to mid-September of each year.

Table 2. Area under the disease progress curve of asparagus cultivars infected with Puccinia asparagi in plots near Prosser, WA, from 1988 to $1995^{\mathrm{y}}$

\begin{tabular}{|c|c|c|c|c|c|c|c|c|}
\hline \multirow[b]{2}{*}{ Cultivar } & \multicolumn{8}{|c|}{ Year } \\
\hline & 1988 & 1989 & 1990 & 1991 & 1992 & 1993 & 1994 & 1995 \\
\hline Jersey Giant & $16 \mathrm{a}$ & $405 \mathrm{a}$ & $2 \mathrm{a}$ & $49 \mathrm{ab}$ & $434 \mathrm{a}$ & $56 \mathrm{a}$ & $52 \mathrm{a}$ & 190 a \\
\hline Delmonte-361 & $22 \mathrm{a}$ & $583 \mathrm{a}$ & $4 \mathrm{a}$ & $12 \mathrm{a}$ & $326 \mathrm{a}$ & $36 \mathrm{a}$ & $47 \mathrm{a}$ & $252 \mathrm{a}$ \\
\hline UC-157 & $22 \mathrm{a}$ & $624 \mathrm{a}$ & $8 \mathrm{a}$ & $43 a b$ & $394 \mathrm{a}$ & $30 \mathrm{a}$ & $81 \mathrm{a}$ & $225 \mathrm{a}$ \\
\hline Lucullus $310^{z}$ & $48 \mathrm{bc}$ & $1,089 \mathrm{~b}$ & $20 \mathrm{ab}$ & $121 \mathrm{ab}$ & $905 \mathrm{~b}$ & $150 a b$ & $336 \mathrm{~b}$ & $474 \mathrm{ab}$ \\
\hline Lucullus $234^{\mathrm{z}}$ & $50 \mathrm{bc}$ & $1,240 \mathrm{~b}$ & $43 a b c$ & $154 \mathrm{bc}$ & $1,223 b c$ & $167 \mathrm{ab}$ & $364 \mathrm{~b}$ & $571 \mathrm{ab}$ \\
\hline Tainan $1^{\mathrm{z}}$ & $50 \mathrm{bc}$ & $1,641 \mathrm{c}$ & $43 a b c$ & $150 \mathrm{bc}$ & $1,057 \mathrm{bc}$ & $241 \mathrm{~b}$ & $305 \mathrm{~b}$ & $836 b c$ \\
\hline Larac $^{\mathrm{z}}$ & $46 \mathrm{~b}$ & $1,161 \mathrm{~b}$ & $99 \mathrm{~d}$ & $273 \mathrm{~cd}$ & $1,212 \mathrm{bc}$ & $222 \mathrm{~b}$ & $1,147 \mathrm{~d}$ & $1,040 \mathrm{c}$ \\
\hline $\mathrm{Cito}^{\mathrm{z}}$ & $58 \mathrm{c}$ & $1,792 \mathrm{c}$ & $69 \mathrm{bcd}$ & $272 \mathrm{~cd}$ & $1,290 \mathrm{~cd}$ & $237 \mathrm{~b}$ & $1,111 \mathrm{~d}$ & $1,126 \mathrm{c}$ \\
\hline Gynlimz $^{2}$ & $50 \mathrm{bc}$ & $1,244 \mathrm{~b}$ & $80 \mathrm{~cd}$ & $315 \mathrm{~d}$ & $1,587 \mathrm{~d}$ & $233 \mathrm{~b}$ & $850 \mathrm{c}$ & $1,658 \mathrm{~d}$ \\
\hline Largo $17-3^{z}$ & $50 \mathrm{bc}$ & $1,705 \mathrm{c}$ & $122 \mathrm{~d}$ & $546 \mathrm{e}$ & $2,255 \mathrm{e}$ & $430 \mathrm{c}$ & $1,281 \mathrm{~d}$ & $1,598 \mathrm{~d}$ \\
\hline Franklim ${ }^{z}$ & $80 \mathrm{~d}$ & $2,759 \mathrm{~d}$ & $357 \mathrm{e}$ & $941 \mathrm{f}$ & $2,979 \mathrm{f}$ & $817 \mathrm{~d}$ & $2,190 \mathrm{e}$ & $2,399 \mathrm{e}$ \\
\hline
\end{tabular}

${ }^{y}$ Values with the same letter within a column are not significantly different at $P=0.05$ according to Fisher's protected LSD. Values are means of five replicates.

Rust severity was estimated using the modified Cobb's scale for cereal rust at 14-day intervals, usually from mid-June to mid-September of each year.

${ }^{\mathrm{z}}$ Cultivar from Europe. 
Interviews with asparagus growers, field consultants and the manager of the Washington Asparagus Commission revealed a shift in asparagus cultivars beginning in 1996 from rust-susceptible to rust-resistant cultivars. Rust-resistant cultivars included Jersey Giant, Jersey Titan, Jersey Centennial, Jersey Knight, and Delmonte-361. By 2002, rust-resistant cultivars made up over $96 \%$ of the asparagus plantings. During the period from 1996 to 2011, rust was not observed by the author nor reported by growers and field consultants to be a problem in fields with rust-resistant cultivars.

\section{Discussion}

The durability of rust resistance in asparagus cultivars can never be conclusively proven because a race of the pathogen may arise in the future that overcomes the resistance. A practical definition of general or durable resistance was given by Caldwell (5) as "resistance that experience and adequate testing in nature have shown to confer an enduring and stable protection against a pathogen or disease." By this criterion, the slow-rusting resistance in Jersey Titan, Jersey Centennial, and Jersey Giant is a stable type of resistance. A more restrictive definition of durable resistance was given by Johnson $(22,23)$ as "resistance that remains effective during its prolonged and widespread use in an environment favorable to the disease." Examples of durable resistance are found in corn to $P$. sorghi (14); in high-temperature, adult-plant resistance in wheat to P. striiformis (27); in 'Knox' wheat to Erysiphe graminis (32); and in several other cases $(11,23,28,37)$. However, meeting the criteria of Johnson's definition is difficult for a minor crop such as asparagus that is not grown over a wide area.

Resistance to rust in Jersey Centennial, Jersey Giant, and Jersey Titan has been effective for many years. The pollen parent used for developing Jersey Centennial, Jersey Giant, Jersey Titan, and other Jersey rust-resistant cultivars was selected from a 15-year-old field of Mary Washington asparagus in New Jersey in 1960 (7-9). Jersey Centennial was resistant in tests at two sites in Minnesota in 1981
(2) and in this study. In addition, Jersey Centennial, Jersey Giant, and Jersey Titan have been grown in central Washington since 1983, and the Jersey and Delmonte-361 cultivars have been the predominant cultivars in Washington since approximately 1996, periods of 29 and 16 years, respectively. During the same time periods, weather in the region has been frequently favorable for rust development (unpublished data). Consequently, Johnson's definition $(22,23)$ of durable resistance can be considered satisfied for slow-rusting resistance in the asparagus cultivars evaluated.

Moderately resistant selections have been made from Mary Washington (17), which was first released as a rust-resistant cultivar prior to 1919 (29). Although severe rust outbreaks occurred on selections of Mary Washington in Illinois in the 1940s and 1950s, and moderate to high levels of rust occurred on a selection of Mary Washington in this study, it is not known if more aggressive strains of the pathogen had been selected or if the host had been unintentionally reselected for susceptibility (17). The latter is likely since seed from individual plants in commercial fields were often collected to establish new plantings. In years with little or no rust, there was no indication of which source plants were resistant, and hence seed from susceptible plants could have been selected.

Asparagus cultivars grown in south-central Washington consist of heterogeneous populations. Cultivars are mostly either openpollinated or clonal hybrids from heterozygous parents, and considerable heterogeneity for rust resistance exists within asparagus cultivars (17). In addition to the effect of rust resistance, the heterogeneous mixture of rust-resistant plants within resistant cultivars of asparagus may produce an effect similar to cultivar mixtures in restricting the spread of the pathogen in a crop (38). The heterogeneity within partially resistant asparagus cultivars may also exert less selection pressure on the pathogen population to overcome various components of partial resistance in the host, such as long latent periods and lower infection frequency, than in cultivars consisting of homogenous clones with partial resistance (17).

Table 3. Rank for area under the disease progress curve (AUDPC) of eight asparagus cultivars infected with Puccinia asparagi in plots near Prosser, WA, from 1983 to $1990^{z}$

\begin{tabular}{|c|c|c|c|c|c|c|c|c|c|}
\hline \multirow[b]{2}{*}{ Cultivar } & \multicolumn{9}{|c|}{ Year } \\
\hline & 1983 & 1984 & 1985 & 1986 & 1987 & 1988 & 1989 & 1990 & Mean \\
\hline Jersey Titan & 1 & 1 & 1 & 1 & 1 & 1 & 1 & 1 & $1.0 \mathrm{a}$ \\
\hline Jersey Centennial & 2 & 2 & 3 & 2 & 3 & 3 & 2 & 2 & $2.4 \mathrm{~b}$ \\
\hline Jersey Giant & 4 & 4 & 2 & 3 & 2 & 2 & 5 & 4 & $3.3 \mathrm{c}$ \\
\hline Delmonte-361 & 3 & 3 & 4 & 5 & 4 & 4 & 3 & 5 & $3.9 \mathrm{~cd}$ \\
\hline UC-157 & 5 & 5 & 5 & 4 & 5 & 5 & 4 & 3 & $4.5 \mathrm{~d}$ \\
\hline Mary Washington & 6 & 6 & 6 & 6 & 6 & 6 & 6 & 6 & $6.0 \mathrm{e}$ \\
\hline Wash T2 & 8 & 7 & 7 & 7 & 7 & 7 & 7 & 7 & $7.1 \mathrm{f}$ \\
\hline WSU-1 & 7 & 8 & 8 & 8 & 8 & 8 & 8 & 8 & $7.9 \mathrm{~g}$ \\
\hline
\end{tabular}

${ }^{\mathrm{z}}$ Ranks are based on the mean AUDPC of six replicates. Mean values followed by the same letter are not significantly different at $P=0.05$ according to Fisher's protected LSD.

Table 4. Rank for area under disease progress curve (AUDPC) of 11 asparagus cultivars infected with Puccinia asparagi in plots near Prosser, WA, from 1988 to $1995^{y}$

\begin{tabular}{|c|c|c|c|c|c|c|c|c|c|}
\hline \multirow[b]{2}{*}{ Cultivar } & \multicolumn{9}{|c|}{ Year } \\
\hline & 1988 & 1989 & 1990 & 1991 & 1992 & 1993 & 1994 & 1995 & Mean \\
\hline Jersey Giant & 1 & 1 & 1 & 3 & 3 & 3 & 2 & 1 & $1.9 \mathrm{a}$ \\
\hline Delmonte-361 & 2 & 2 & 3 & 1 & 1 & 2 & 1 & 3 & $1.9 \mathrm{a}$ \\
\hline UC-157 & 2 & 3 & 2 & 2 & 2 & 1 & 3 & 2 & $2.1 \mathrm{a}$ \\
\hline Lucullus $310^{\mathrm{z}}$ & 5 & 4 & 4 & 4 & 4 & 4 & 5 & 4 & $4.4 \mathrm{~b}$ \\
\hline Lucullus $234^{\mathrm{z}}$ & 6 & 6 & 5 & 6 & 7 & 5 & 6 & 5 & $5.8 \mathrm{c}$ \\
\hline Tainan $1^{\mathrm{z}}$ & 6 & 8 & 5 & 5 & 5 & 9 & 4 & 6 & $6.0 \mathrm{c}$ \\
\hline $\operatorname{Larac}^{\mathrm{z}}$ & 4 & 5 & 9 & 8 & 6 & 6 & 9 & 7 & $6.8 \mathrm{~cd}$ \\
\hline Gynlim $^{z}$ & 6 & 7 & 8 & 9 & 9 & 7 & 7 & 10 & $7.9 \mathrm{de}$ \\
\hline $\mathrm{Cito}^{\mathrm{z}}$ & 10 & 10 & 7 & 7 & 8 & 8 & 8 & 8 & $8.3 \mathrm{ef}$ \\
\hline Largo17-3z & 6 & 9 & 10 & 10 & 10 & 10 & 10 & 9 & $9.3 \mathrm{f}$ \\
\hline Franklimz & 11 & 11 & 11 & 11 & 11 & 11 & 11 & 11 & $11.0 \mathrm{~g}$ \\
\hline
\end{tabular}

${ }^{y}$ Ranks are based on the mean AUDPC of five replicates. Mean values followed by the same letter are not significantly different at $P=0.05$ according to Fisher's protected LSD.

${ }^{z}$ Cultivar from Europe. 
Rust severity varied on the asparagus cultivars over 13 years in field plots of this study, but specific cultivars were always the most resistant, including Jersey Giant and Delmonte-361, and other cultivars were always the most susceptible, including WSU-1 and Franklim. Johnson $(22,23)$ cited examples in which the slowrusting or partial resistance of particular cultivars was race-specific and attacked by certain races. However, the most resistant cultivars always had lower disease levels than the most susceptible cultivars. Physiological races of $P$. asparagi have not been detected (unpublished data) and may not be, as long as asparagus populations are heterogeneous. The heterogeneous structure of asparagus cultivars should add stability to the rust resistance system $(3,33)$.

Rust nurseries were used in this study where teliospores were allowed to overwinter on asparagus debris and epidemics originated for resulting basidiospores. Abundant pycnia and aecia were present and allowed to develop on asparagus shoots in early spring each year of the study except for 1983, when border rows around plots were artificially inoculated. This allowed the asparagus genotypes to be tested against a relatively high level of genetic variability of the pathogen. In addition, overhead sprinkler irrigation was applied at night to favor rust development. Durable resistance to crown rust in oats was selected in irrigated nurseries in Minnesota where $P$. coronata was allowed to overwinter on infected oat straw and pycnia and aecia then developed on hawthorn, the alternate host (11).

Rust was much more severe in the plots of resistant cultivars in this study than had been observed in commercial fields of slowrusting cultivars in south-central Washington over a 29-year period. This is because rust-favorable wet periods were imposed by timely irrigation at night and because plots of resistant cultivars were showered with inoculum from aecia in early spring and from uredinia formed on susceptible plants growing nearby.

The area cropped to asparagus declined from over 13,000 ha in the mid-1980s to 10,300 ha in $1993,9,000$ ha in $1997,7,400$ ha in 2002, and 2,850 ha each in 2007 and 2011 (1). The decline was due to high labor costs to hand harvest the crop and due to stand decline, mainly from Fusarium crown and root rot caused by several species of Fusarium (10). Rust-susceptible cultivars were the first to be removed because of rust management costs and because severe rust infections over a period of years weakened crowns and contributed to stand decline $(10,20)$. Rust-resistant cultivars were used to establish new plantings, and over $96 \%$ of production is currently with slow-rusting resistant cultivars.

Environmental factors such as relatively high inoculum levels, excessive plant nutrition, and disease-favorable weather may elevate disease levels on partially resistant cultivars compared to less favorable conditions $(15,25,31,35,36)$. Consequently, managing rust with slow-rusting resistance in asparagus should be supplemented with sanitation practices that eliminate development of aecia on volunteer asparagus plants, on seedlings in nurseries, and on nonharvested asparagus plants in fields in the spring (18). In addition, the application of excessive amounts of overhead sprinkler irrigation and excessive amounts of nitrogen fertilizer should be avoided in a semiarid environment such as south-central Washington. Cultural practices may need to be supplemented with fungicides in environments with abundant rainfall, mists, or dews.

\section{Acknowledgments}

We thank Thomas Cummings for assistance with data analysis, and R. F. Line and W. Chen for critical review of the manuscript. PPNS no. 0471, Department of Plant Pathology, College of Agricultural, Human, and Natural Resource Sciences, Agricultural Research Center project no. 0678, Washington State University, Pullman, WA 99164-6430.

\section{Literature Cited}

1. Anonymous. 2011. National Agriculture Statistics Service. USDA. http://www.Agcensus.usda.gov.

2. Blanchette, B. L., Groth, J. V., and Waters, L., Jr. 1982. Evaluation of asparagus for resistance to Puccinia asparagi. Plant Dis. 66:904-906.

3. Browning, J. A. 1974. Relevance of knowledge about natural ecosystems to development of pest management programs for agro-ecosystems. Proc. Am. Phytopathol. Soc. 1:191-199.

4. Browning, J. A., Simons, M. D., and Torres, E. 1977. Managing host genes:
Epidemiologic and genetic concepts. Pages 191-212 in: Plant Pathology: An Advanced Treatise. Vol. 1. J. G. Horsfall and E. B. Cowling, eds. Academic Press, New York.

5. Caldwell, R. M. 1968. Breeding for general and/or specific plant disease resistance. Pages 263-275 in: Proc. 3rd Int. Wheat Genet. Sympos. K. W. Finlay and D. W. Shepherd, eds. Aust. Acad. Sci., Canberra.

6. Ellison, J. H. 1986. Asparagus breeding. Pages 521-569 in: Breeding Vegetable Crops. M. J. Bassett, ed. AVI Publishing Co., Westport, CT.

7. Ellison, J. H., Garrison, S. A., and Kinelski, J. J. 1990. Male asparagus hybrids: 'Jersey Gem,' Jersey General,' 'Jersey King,' 'Jersey Knight,' and 'Jersey Titan.' HortScience 25:816-817.

8. Ellison, J. H., and Kinelski, J. J. 1985. 'Jersey Giant', An all-male asparagus hybrid. HortScience 20:1141.

9. Ellison, J. H., Vest, G., and Langolis, R. W. 1981. 'Jersey Centennial' asparagus. HortScience 16:349.

10. Elmer, W. H., Johnson, D. A., and Mink, G. I. 1996. Epidemiology and management of the diseases causal to asparagus decline. Plant Dis. 80:117-125.

11. Heagle, A. S., and Moore, M. B. 1970. Some effects of moderate adult resistance to crown rust of oats. Phytopathology 60:461-466.

12. Helper, P. R., Thompson, A. E., and McCollum, J. P. 1957. Inheritance of resistance to asparagus rust. Ill. Agric. Exp. Stn. Bull. 607.

13. Hodgson, W. A. 1961. Laboratory testing of the potato for partial resistance to Phytophthora infestans. Am. Potato J. 38:259-264.

14. Hooker, A. L. 1969. Widely based resistance to rust in corn. Pages 28-34 in: Disease consequences of intensive culture of field crops. J. A. Browning, ed. Iowa Agric. Exp. Stn. Spec. Rep. 64.

15. Johnson, D. A. 1980. Effect of low temperature on the latent period of slow and fast rusting winter wheat genotypes. Plant Dis. 64:1006-1008.

16. Johnson, D. A. 1986. Two components of slow-rusting in asparagus infected with Puccinia asparagi. Phytopathology 76:208-211.

17. Johnson, D. A. 1989. Variation for rust resistance within asparagus cultivars. Plant Dis. 73:309-312

18. Johnson, D. A. 1990. Development of rust on asparagus cultivars after inoculation with basidiospores, aeciospores, and unrediniospores of Puccinia asparagi. Phytopathology 80:321-325.

19. Johnson, D. A., and Gilmore, E. C. 1980. Breeding for resistance to pathogens in wheat. Pages 263-275 in: Biology and Breeding for Resistance to Arthropods and Pathogens in Agricultural Plants. M. K. Harris, ed. Texas A\&M University, College Station, TX.

20. Johnson, D. A., and Lunden, J. D. 1992. Effect of rust on yield of susceptible and resistant asparagus cultivars. Plant Dis. 76:84-86.

21. Johnson, D. A., and Peaden, R. N. 1993. Rust resistance in asparagus $F_{1}$ hydrid populations. Plant Dis. 77:1144-1148.

22. Johnson, R. 1979. Letter to the Editor: The concept of durable resistance Phytopathology 69:198-199.

23. Johnson, R. 1984. A critical analysis of durable resistance. Annu. Rev. Phytopathol. 22:309-330.

24. Kahn, R. P., Anderson, H. W., Hepler, P. R., and Linn, M. B. 1952. An investigation of asparagus rust in Illinois, its casual agent and its control. Ill. Agric. Exp. Stn. Bull. 559.

25. Kroll, R. E., and Eide, C. J. 1981. Effect of inoculum concentrations of Phytophthora infestans on potato late blight. Am. Potato J. 58:153-161.

26. Kuhn, R. C., Ohm, H. W., and Shaner, G. E. 1978. Slow leaf-rusting resistance in wheat against twenty-two isolates of Puccinia recondita. Phytopathology 68:651-656.

27. Line, R. F., and Chen, X. 1995. Successes in breeding for and managing durable resistance to wheat rusts. Plant Dis. 79:1254-1255.

28. Luke, H. H., Chapman, W. H., and Barnett, R. D. 1972. Horizontal resistance of red rust proof oats to crown rust. Phytopathology 62:414-417.

29. Norton, J. B. 1913. Methods used for breeding asparagus for rust resistance U.S. Bur. Plant Ind. Bull. 263

30. Peterson, R. E., Campbell, A. B., and Hannah, A. E. 1948. A diagrammatic scale for estimating rust intensity on leaves and stems of cereals. Can. J. Res. 26:496-500.

31. Qayoum, A., and Line, R. F. 1985. High-temperature adult-plant resistance to stripe rust of wheat. Phytopathology 75:1121-1125.

32. Shaner, G. 1973. Evaluation of slow-mildewing resistance of Knox wheat in the field. Phytopathology 63:867-872.

33. Sztejnberg, A., and Wahl, I. 1976. Mechanisms and stability of slow stem rusting resistance in Avena sterilis. Phytopathology 66:74-80.

34. Thompson, A. E., and Helper, P. R. 1956. A summary of resistance and susceptibility to Puccinia asparagi DC within the genus Asparagus. Plant Dis. Rep. 40:133-137.

35. Thurston, H. D., Heidreick, L. E., and Guzman, J. 1962. Partial resistance to Phytophthora infestans (Mont.) de Bary within the coleccion central Colombiana. Am. Potato J. 39:63-69.

36. Wilcoxson, R. D. 1980. Effects of fertilizers on slow rusting in wheat Phytopathology 70:930-932.

37. Wilcoxson, R. D. 1981. Genetics of slow rusting in cereals. Phytopathology 71:989-993

38. Wolfe, M. S. 1985. The current status and prospects of multiline cultivars and variety mixtures for disease resistance. Annu. Rev. Phytopathol. 23:251-273. 